\title{
The Determination of Chromium-Oxygen Interactions in Levitated Iron Alloy Droplets*
}

\author{
By F.C.L. LARCHE'** and A. MCLEAN***
}

\begin{abstract}
Synopsis
The dissolution of oxygen in liquid iron and iron-chromium alloys has been investigated by means of a levitation melting procedure. The oxygen potential of the system was controlled with $\mathrm{H}_{2} / \mathrm{H}_{2} \mathrm{O}$ and $\mathrm{CO} / \mathrm{CO}_{2}$ gas mixtures. With $\mathrm{H}_{2} / \mathrm{H}_{2} \mathrm{O}$ and liquid iron, thermal diffusion effects are significant and results obtained at steady state should not be used to determine equilibrium constants directly. With $\mathrm{CO} / \mathrm{CO}_{2}$, the steady state data are in closer agreement with published equilibrium values. Despite the existance of thermal diffusion it has been shown that the levitation technique can be employed to establish the relative effect of one element on the chemical behaviour of another. The influence of up to $24 w t^{\circ}$ chromium on the activity coefficient of oxygen in liquid iron has been determined for temperatures between $1550^{\circ}$ and $1750^{\circ} \mathrm{C}$. Interaction parameters from $\mathrm{H}_{2} / \mathrm{H}_{2} \mathrm{O}$ experiments were in good agreement with the values obtained using $\mathrm{CO} / \mathrm{CO}_{2}$. While comparison with published data for several gas/metal and slag/metal studies indicates reasonable agreement, the inte astion effects appear to be much stronger than those measured using line-stabilized zirconia cells.
\end{abstract}

\section{Introduction}

There have been a number of investigations which describe the effect of chromium on the behaviour of oxygen dissolved in liquid iron. ${ }^{1-14)}$ Much of the work, however, has been confined to chromium levels below $12 \mathrm{wt} \%$ and to temperatures in the vicinity of $1600{ }^{\circ} \mathrm{C}$. All of the studies have been performed using oxide crucibles and frequently the melts have been saturated with respect to one of the oxides of chromium. Under these conditions it is not always possible to ensure that samples taken for oxygen analysis are free from entrapped oxides and hence representative of the original melt composition. In the present study, problems associated with melt contamination from crucible material and oxide solubility products have been avoided by using a levitation melting procedure to study chromium-oxygen interactions in liquid iron containing up to $24 \mathrm{wt} \%$ chromium, under conditions which were sufficiently reducing to prevent the formation of chromium oxides at temperatures between $1550^{\circ}$ and $1750^{\circ} \mathrm{C}$. Kershaw et al..$^{15)}$ have used this technique to study oxygen activities in iron-vanadium alloys and have pointed out that with hydrogen/ water-vapour mixtures to control the oxygen potential of the gas phase, thermal diffusion effects can lead to uncertainty in the gas composition at the droplet interface. For this reason their data were not used to calculate equilibrium constants. However by expressing the results in terms of an apparent equilibrium ratio, vanadium-oxygen interaction parameters were deter- mined which were in good agreement with data from crucible experiments where thermal diffusion effects were eliminated by bubbling the gas through the melt. In the present work, further information has been obtained on the use of levitation melting to determine oxygen solution data for pure iron and iron-chromium alloys, by equilibrating droplets with $\mathrm{H}_{2} / \mathrm{H}_{2} \mathrm{O}$ and $\mathrm{CO} / \mathrm{CO}_{2}$ gas mixtures.

\section{Experimental Procedure}

A diagram of the levitation assembly is shown in Fig. 1. The experimental aspects of this procedure have been discussed in detail by Kershaw et al. ${ }^{15)}$ In brief, power to the levitation coil was supplied from a $450 \mathrm{kHz}, 10 \mathrm{~kW}$ generator, via a $7.5: 1$ step down transformer. The droplet was levitated inside a $15 \mathrm{~mm}$ vycor tube which was fitted with a rotatable aluminum base-plate containing a charging rod, a copper quenching mould and an observation port for temperature measurement by means of a two-colour pyrometer. Details on pyrometer calibration for use with a levitation system have been given previously. ${ }^{15)}$ The temperatures reported are considered to be accurate to within $\pm 10^{\circ} \mathrm{C}$. The oxygen potential of the atmosphere was controlled with either $\mathrm{CO} / \mathrm{CO}_{2}$ or $\mathrm{H}_{2} / \mathrm{H}_{2} \mathrm{O}$
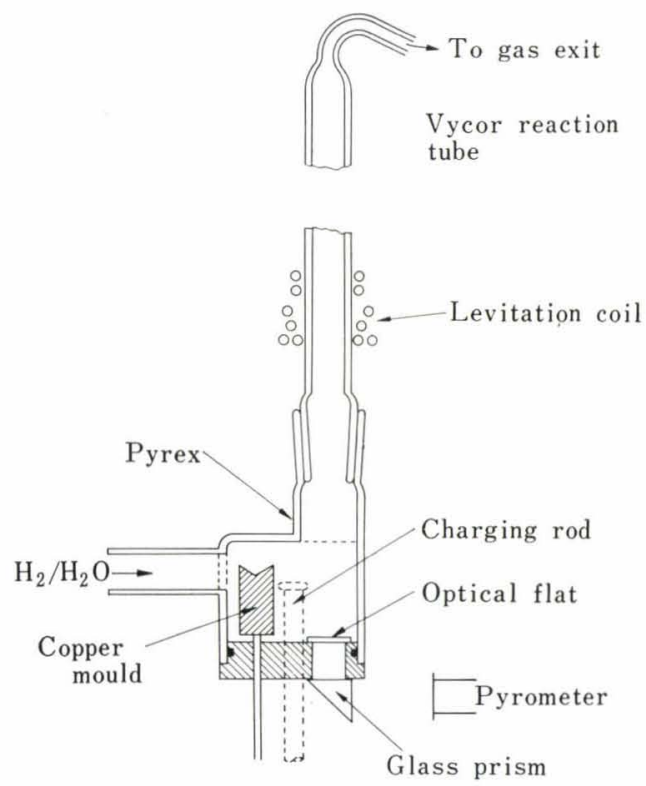

Fig. 1. The reaction chamber for levitation melting experiments

* Received July 14, 1972.

** Formerly Department of Metallurgy and Materials Science, McMaster University, Hamilton, Canada.

*** Formerly Department of Metallurgy and Materials Science, McMaster University, Hamilton, Canada, now at Department of Metallurgy and Materials Science, University of Toronto, Canada. 
gas mixtures. High purity $\mathrm{CO} / \mathrm{CO}_{2}$ mixtures were obtained with analysis from the supplier, while the $\mathrm{H}_{2} / \mathrm{H}_{2} \mathrm{O}$ mixtures were prepared by passing hydrogen over platinized asbestos and then through a water bath maintained within $0.1^{\circ} \mathrm{C}$ of the desired temperature in the range $30^{\circ}$ to $47^{\circ} \mathrm{C}$. Higher water vapour ratios were obtained by replacing the hydrogen with helium-hydrogen mixtures. In order to avoid oxide formation with the high chromium alloys, low water vapour ratios were produced by passing hydrogen over a mixture of oxalic acid and the acid dihydrate. ${ }^{16-19}$ ) The behaviour of the saturator systems was checked with magnesium perchlorate bulbs and found to be within 0.5 to $1 \%$ of the expected values. Moisture condensation within the gas line from the saturator to the reaction chamber was prevented by means of a nichrome wire heater. Because of the difference in thermal properties, gas flow rates of approximately 20 and $0.5 \mathrm{l} / \mathrm{min}$ were required with $\mathrm{CO} / \mathrm{CO}_{2}$ and $\mathrm{H}_{2} / \mathrm{H}_{2} \mathrm{O}$ mixtures respectively, in order to maintain the droplet temperatures at the desired level.

In a typical experiment a one gram sample of Armco iron, or an iron-chromium alloy, was placed within the levitation chamber by means of the charging rod. After flushing with helium, the specimen was levitated, deoxidized in hydrogen for $5 \mathrm{~min}$, and then exposed to either $\mathrm{CO} / \mathrm{CO}_{2}$ or $\mathrm{H}_{2} / \mathrm{H}_{2} \mathrm{O}$ for 5 to 10 min until steady state with respect to oxygen dissolution had been achieved. After quenching, samples were analysed for oxygen by inert gas fusion and for chromium by the standard oxidation procedure. Uncertainty in the oxygen analysis is less than $10 \mathrm{ppm}$, while the chromium values reported are accurate to within $2 \%$ of the amount present.

\section{Discussion}

\section{Dissolution of Oxygen in Liquid Iron}

Kershaw et al. have reported data for the dissolution of oxygen in levitated iron droplets exposed to hydrogen/water vapour gas mixtures. ${ }^{15}$ ) Their data were significantly different from those obtained with conventional crucible techniques where precautions were taken to minimize error due to thermal diffusion. ${ }^{7,20,21)}$ The values of Kershaw et al. for the apparent equilibrium constant were unaffected by an eight fold change in gas flow rate. However when the mean molecular weight of the gas mixture was increased by the addition of argon, the values were in closer agreement with the data from crucible studies. These effects were attributed to the influence of thermal diffusion on the gas composition at the droplet interface and they have been confirmed in the present work.

Toop and Richardson have published data for the solution of oxygen in molten levitated nickel droplets which were equilibrated with $\mathrm{CO} / \mathrm{CO}_{2}$ gas mixtures. ${ }^{22)}$ These gases are not as susceptible to thermal diffusion as $\mathrm{H}_{2} / \mathrm{H}_{2} \mathrm{O}$ and good agreement was observed between the levitation results and those from crucible experiments. During the course of the present study a series of experiments was made in which molten iron droplets were equilibrated with $\mathrm{CO} / \mathrm{CO}_{2}$ mixtures.
The reaction under consideration can be written:

$$
\mathrm{CO}+\underline{\mathrm{O}}=\mathrm{CO}_{2}
$$

for which: $K_{1}=p_{\mathrm{CO}_{2}} / p_{\mathrm{Co}}\left[a_{0}\right]$, where $K_{1}$ is the equilibrium constant and $a_{0}$ is the oxygen activity based on the hypothetical $1 \mathrm{wt} \%$ solution. The equilibrium ratio for the reaction is :

$$
K_{1}^{\prime}=p_{\mathrm{CO}_{2}} / p_{\mathrm{Co}}[\mathrm{wt} \% \mathrm{O}]
$$

The variation of the equilibrium ratio with oxygen content was studied at $1600^{\circ} \mathrm{C}$ with gas mixtures ranging from 0.5 to $15 \% \mathrm{CO}_{2}$. The results are shown in Fig. 2. A least mean square treatment of the data showed that the deviation from Henry's law was not significant. This is in agreement with the findings of Tankins et al. ${ }^{23)}$ The discrepancy caused by equating $K_{1}$ and $K_{1}^{\prime}$ for the iron-oxygen binary, particularly for oxygen levels below $500 \mathrm{ppm}$, is considered to be well within the error limits of the oxygen analysis and is therefore ignored in further treatment of the data. The influence of temperature on $K_{1}$ was investigated from $1550^{\circ}$ to $1750^{\circ} \mathrm{C}$ using a gas mixture containing $5.34 \% \mathrm{CO}_{2}$. The least mean square line corresponding to the present work in Fig. 3 has the equation:

$$
\log K_{1}=7630 / \mathcal{T}( \pm 660)-4.085( \pm 0.064)
$$

from which

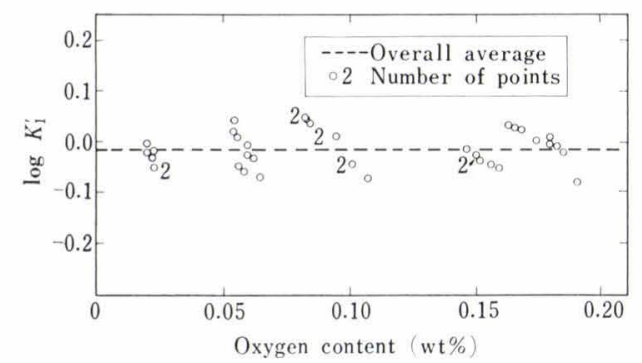

Fig. 2. The effect of oxygen content on the equilibrium ratio at $1600^{\circ} \mathrm{C}$ for the reaction: $\mathrm{CO}+\underline{\mathrm{O}}=\mathrm{CO}_{2}$

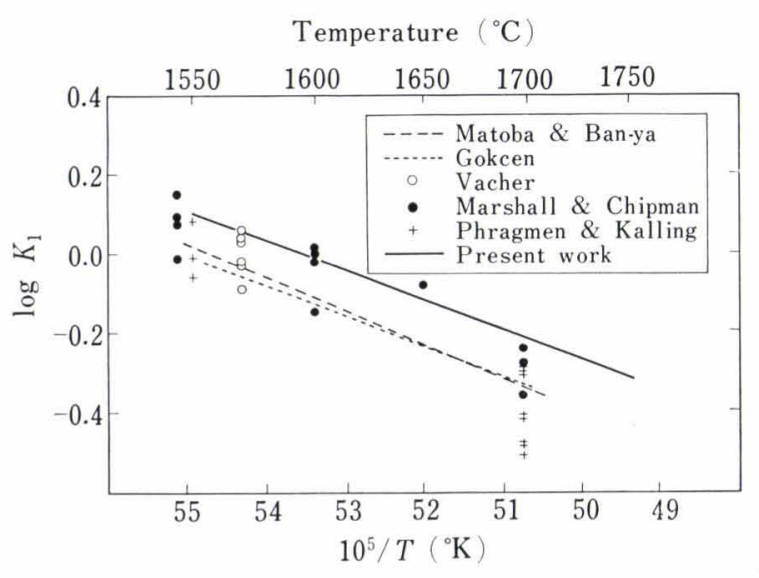

Fig. 3. Comparison of various data for the effect of temperature on the equilibrium constant for the reaction: $\mathrm{CO}+\mathrm{O}=\mathrm{CO}_{2}$ 


$$
\Delta G_{1}^{\circ}=-34910+18.69 T
$$

For comparison purposes, results obtained by several other workers ${ }^{24-28)}$ who have studied this reaction using the crucible technique are included in Fig. 3. The solution of oxygen in liquid iron has been investigated most frequently with $\mathrm{H}_{2} / \mathrm{H}_{2} \mathrm{O}$ mixtures and for comparison with data from these studies, particularly levitation work, it is convenient to combine Eq. (2) with the free energy change for the water gas reaction: ${ }^{29)}$

$$
\begin{aligned}
\mathrm{H}_{2}+\mathrm{CO}_{2} & =\mathrm{H}_{2} \mathrm{O}+\mathrm{CO} \\
\Delta G^{\circ} & =6355-6.24 T
\end{aligned}
$$

Thus for the reaction:

$$
\begin{aligned}
\mathrm{H}_{2}+\underline{\mathrm{O}} & =\mathrm{H}_{2} \mathrm{O} \\
\Delta G_{2}^{\circ} & =-28555+12.45 \mathrm{~T} .
\end{aligned}
$$

and

$$
\log K_{2}=6242 / T-2.72
$$

The effect of temperature on $\log K_{2}$ as represented by Eq. (5) is shown in Fig. 4 together with other correlations from the literature for this reaction. ${ }^{7,20,21,23,30,31)}$ Included in this figure, is a line representing the results from over sixty experiments performed during the present investigation in which levitated droplets were equilibrated with $\mathrm{H}_{2} / \mathrm{H}_{2} \mathrm{O}$ mixtures. These results are within 0.04 logarithmic units of the previous data from the levitation work by Kershaw et al. ${ }^{15)}$ It is evident from these findings that thermal diffusion effects are substantial when $\mathrm{H}_{2} / \mathrm{H}_{2} \mathrm{O}$ mixtures are used to control the oxygen potential of the system for levitation experiments of the type described here and for this reason the data should not be used directly to evaluate equilibrium constants. However it should be noted, that Sunderland et al. ${ }^{32}$ ) have combined the results of the present work with certain terms which were determined from consideration of thermal diffusion criteria and the kinetic theory of gases. The values which were then obtained for the equilibrium

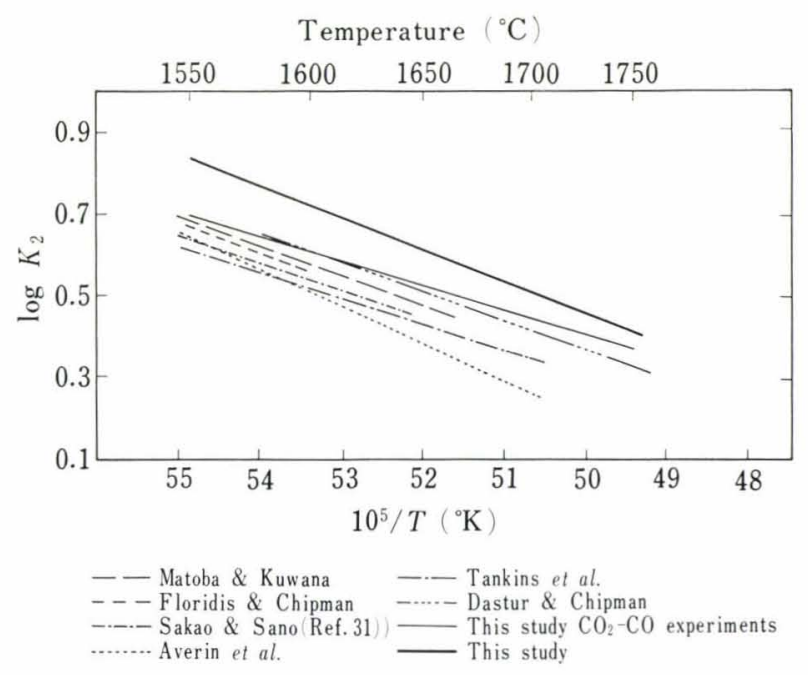

Fig. 4. Comparison of various data for the effect of temperature on the equilibrium constant for the reaction: $\mathrm{H}_{2}+\underline{\mathrm{O}}=\mathrm{H}_{2} \mathrm{O}$ constant were in very good agreement with previous data for this reaction. ${ }^{21,23,31)}$

As would be expected from consideration of the molecular weight ratios, thermal diffusion effects are markedly decreased when $\mathrm{CO} / \mathrm{CO}_{2}$ mixtures are employed. In this case, the data for temperatures in the vicinity of $1550^{\circ}$ to $1600^{\circ} \mathrm{C}$ are within 0.05 logarithmic units of the values from several previous studies, where conditions were adjusted to minimize errors from this source. ${ }^{7,20,21)}$

\section{Chromium-Oxygen Interactions in Liquid Iron}

The major objective of the present study was to provide further evidence that the relative effect of one alloying element on the chemical behaviour of another, as represented by interaction parameters, could be determined by the levitation procedure, in spite of thermal diffusion, provided the gas composition at the droplet interface was not affected by the alloy content of the droplet. Experiments were performed at $50^{\circ} \mathrm{C}$ intervals between $1550^{\circ}$ and $1750^{\circ} \mathrm{C}$ with alloys containing up to $24 \mathrm{wt} \%$ chromium.

The equilibrium constant for the reaction between oxygen dissolved in liquid iron-chromium alloys and $\mathrm{H}_{2}-\mathrm{H}_{2} \mathrm{O}$ gas mixtures is given by:

$$
K_{2}=p_{\mathrm{H}_{2} \mathrm{O}} / p_{\mathrm{H}_{2}} \cdot f_{\mathrm{O}} \cdot[\mathrm{wt} \% \mathrm{O}]
$$

where the reference state for the activity coefficient is based on the infinitely dilute solution.

From Eq. (6),

$$
\log f_{\mathrm{O}}=\log \left(p_{\mathrm{H}_{2} \mathrm{O}} / p_{\mathrm{H}_{2}}[\% \mathrm{O}]\right)-\log K_{2} .
$$

$\log f_{0}$ can also be represented by a Taylor series expansion :

$$
\begin{aligned}
\log f_{\mathrm{O}}= & e_{\mathrm{o}}^{\mathrm{O}}[\% \mathrm{O}]+e_{\mathrm{O}}^{\mathrm{Cr}}[\% \mathrm{Cr}]+r_{\mathrm{o}}^{\mathrm{O}}[\% \mathrm{O}]^{2} \\
& +r_{\mathrm{o}}^{\mathrm{Cr}}[\% \mathrm{Cr}]^{2}+r_{\mathrm{o}}^{\mathrm{O}, \mathrm{Cr}}[\% \mathrm{O}][\% \mathrm{Cr}]+\cdots
\end{aligned}
$$

where the interaction parameters $e_{0}^{0}, e_{0}^{\mathrm{Cr}}$, etc. are defined according to the formalism proposed by Wagner ${ }^{33)}$ and subsequently developed by Lupis and Elliott. ${ }^{34-36)}$ In the present work, the oxygen level is sufficiently low so that terms involving $e_{0}^{0}$ and $r_{0}^{0}$ can be neglected. The parameter $r_{0}^{\mathrm{o}, \mathrm{cr}}$, cannot be determined directly from the data available, however the term involving this parameter is likely to be small in comparison to the other second order term involving the square of the chromium content. This seems reasonable in view of the following empirical relationship ${ }^{36)}$ between second order free energy parameters on a mole fraction scale :

$$
\rho_{i}^{i, j}=\rho_{i}^{i}+\rho_{i}^{j}
$$

With these considerations in mind Eq. (8) becomes:

$$
\log f_{\mathrm{O}}=e_{\mathrm{o}}^{\mathrm{Cr}}[\% \mathrm{Cr}]+r_{\mathrm{o}}^{\mathrm{Cr}}[\% \mathrm{Cr}]^{2}
$$

Combining Eqs. (7) and (9) :

$$
\begin{aligned}
\log \left(p_{\mathrm{H}_{2} \mathrm{O}} / p_{\mathrm{H}_{2}}[\% \mathrm{O}]\right)= & e_{\mathrm{O}}^{\mathrm{Cr}}[\% \mathrm{Cr}] \\
& +r_{\mathrm{O}}^{\mathrm{Cr}}[\% \mathrm{Cr}]^{2}+\log \kappa_{2}
\end{aligned}
$$


Results obtained from experiments conducted at $1600^{\circ} \mathrm{C}$ are given in Table 1, while data for the effect of chromium on the equilibrium ratio are shown in Fig. 5. Values for first and second order free energy parameters were calculated from a least mean square analysis of the data collected at each temperature. The decrease observed in these parameters with increasing temperature is given by :

$$
e_{\mathrm{o}}^{\mathrm{Cr}}=-557.8 / \mathcal{T}+0.240
$$

and

$$
r_{0}^{\mathrm{Cr}}=12.97 / T-6.29 \times 10^{-3} .
$$

From these relationships, the following values are calculated for first and second order enthalpy and entropy parameters on a wt $\%$ basis :

$$
\begin{array}{lll} 
& \text { Enthalpy } & \text { Entropy } \\
\text { First order } & h_{0}^{\mathrm{Cr}}=-2550 & s_{\mathrm{O}}^{\mathrm{Cr}}=-1.10 \\
\text { Second order } & l_{\mathrm{O}}^{\mathrm{Cr}}=59.34 & p_{\mathrm{O}}^{\mathrm{Cr}}=2.88 \times 10^{-2}
\end{array}
$$

The ratio of the first order enthalpy and entropy

\begin{tabular}{|c|c|c|c|c|}
\hline $\begin{array}{l}\text { Experiment } \\
\text { number }\end{array}$ & $\begin{array}{l}\text { Chromium } \\
\text { (wt \%) }\end{array}$ & $\begin{array}{c}\left(p_{\mathrm{H}_{2} \mathrm{O}} / p_{\mathrm{H}_{2}}\right) \\
\left(\times 10^{2}\right)\end{array}$ & $\begin{array}{l}\text { Oxygen } \\
(\mathrm{ppm})\end{array}$ & $\log \frac{p_{\mathrm{H}_{2} \mathrm{O}}}{p_{\mathrm{H}_{2}}[\% \mathrm{O}]}$ \\
\hline 1331 & 0.52 & 5.539 & 121 & 0.661 \\
\hline 1333 & 0.52 & 5.529 & 118 & 0.671 \\
\hline 1334 & 0.52 & 5.529 & 116 & 0.678 \\
\hline 1335 & 0.52 & 5.529 & 127 & 0.639 \\
\hline 1321 & 1.01 & 5.580 & 99 & 0.751 \\
\hline 1322 & 1.01 & 5.584 & 110 & 0.706 \\
\hline 1323 & 1.01 & 5.584 & 113 & 0.694 \\
\hline 1324 & 1.01 & 5.623 & 114 & 0.693 \\
\hline 1325 & 1.01 & 5.623 & 113 & 0.697 \\
\hline 1350 & 1.95 & 5.478 & 160 & 0.535 \\
\hline 1351 & 1.95 & 5.478 & 165 & 0.521 \\
\hline 1353 & 1.95 & 5.482 & 161 & 0.532 \\
\hline 1461 & 7.67 & 1.988 & 92 & 0.335 \\
\hline 1462 & 7.67 & 1.988 & 67 & 0.472 \\
\hline 1463 & 7.67 & 1.988 & 80 & 0.395 \\
\hline 1464 & 9.99 & 1.987 & 102 & 0.290 \\
\hline 1465 & 9.99 & 1.987 & 125 & 0.201 \\
\hline 1466 & 9.99 & 1.986 & 116 & 0.234 \\
\hline 1467 & 15.00 & 1.985 & 195 & 0.008 \\
\hline 1468 & 15.00 & 1.981 & 179 & 0.044 \\
\hline 1469 & 15.00 & 1.984 & 186 & 0.028 \\
\hline 1470 & 19.99 & 1.985 & 281 & -0.151 \\
\hline 1471 & 19.99 & 1.985 & 280 & -0.149 \\
\hline 1472 & 19.99 & 1.987 & 282 & -0.152 \\
\hline 1518 & 24.00 & 0.844 & 156 & -0.267 \\
\hline 1519 & 24.00 & 0.844 & 157 & -0.270 \\
\hline 1520 & 24.00 & 0.844 & 156 & -0.267 \\
\hline
\end{tabular}
parameters on a mole fraction basis, $\eta_{\mathrm{O}}^{\mathrm{Cr}}=-238 \mathrm{kcal}$ and $\sigma_{\mathrm{o}}^{\mathrm{cr}}=-103 \mathrm{cal} /{ }^{\circ} \mathrm{K}$ respectively, yields a value of $2300^{\circ} \mathrm{K}$ for the " characteristic temperature " for ironchromium-oxygen solutions. This represents the temperature at which the solution would become ideal, if the data at lower temperatures were linearly extra-

Table 1. Dissolution of oxygen in iron-chromium alloys at $1600^{\circ} \mathrm{C}$ from $\mathrm{H}_{2} / \mathrm{H}_{2} \mathrm{O}$ gas mixtures polated. ${ }^{37)}$

Combining Eqs. (9), (11), and (12), the activity coefficient of oxygen in liquid iron-chromium alloys is given by:

$$
\begin{aligned}
\log f_{\mathrm{o}}= & (-557.8 / \mathrm{T}+0.240)[\% \mathrm{Cr}] \\
& +\left(12.97 / \mathrm{T}-6.29 \times 10^{-3}\right)[\% \mathrm{Cr}]^{2} .
\end{aligned}
$$

which is valid for chromium concentrations up to $24 \mathrm{wt} \%$ and for temperatures between $1550^{\circ}$ and $1750^{\circ} \mathrm{C}$. The influence of chromium concentration and temperature on the activity coefficient of oxygen is shown graphically in Fig. 6.

Experiments were also performed at $1600^{\circ} \mathrm{C}$ with $\mathrm{CO} / \mathrm{CO}_{2}$ gas mixtures and iron alloys containing up to $10 \mathrm{wt} \%$ chromium. It was determined by calculation, and subsequently confirmed by chemical analysis, that the effect of carbon dissolution from the gas phase on the behaviour of oxygen in the droplets, could be neglected. Treatment of the data was similar to that outlined previously and yielded the following equation for the activity coefficient of oxygen :

$$
\log f_{\mathrm{O}}=-0.058[\% \mathrm{Cr}]+1.25 \times 10^{-3}[\% \mathrm{Cr}]^{2} \ldots
$$

The value for $e_{0}^{\mathrm{Cr}}$ of -0.058 agrees well with that derived from Eq. (11) which was based on the $\mathrm{H}_{2} / \mathrm{H}_{2} \mathrm{O}$ experiments. The second order parameters are approximately $10^{-3}$ and agree within a factor of two.

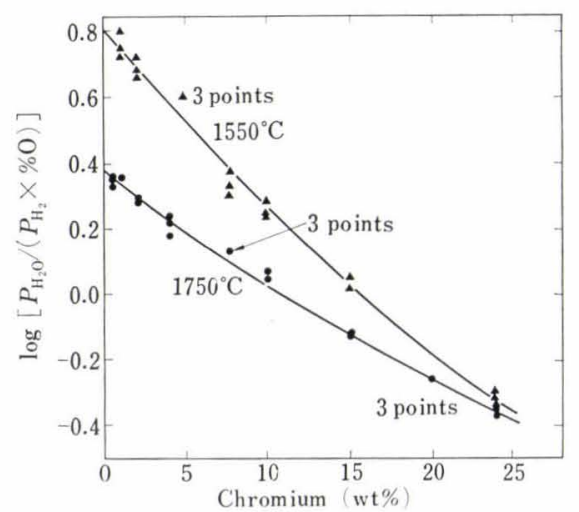

Fig. 5. The effect of chromium on the equilibrium ratio for the reaction: $\mathrm{H}_{2}+\mathrm{O}=\mathrm{H}_{2} \mathrm{O}$

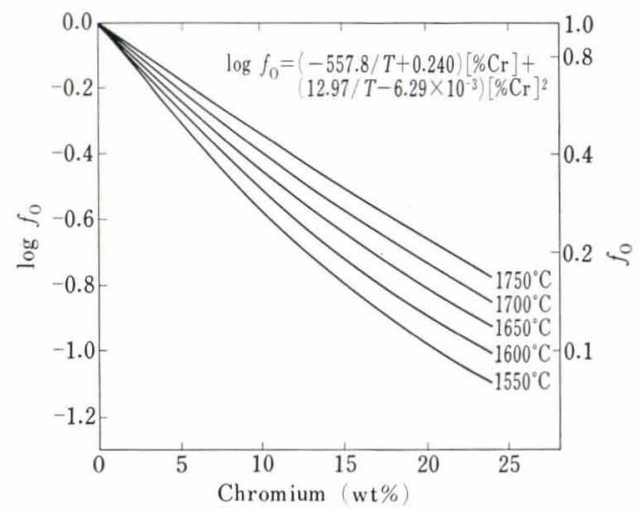

Fig. 6. The effect of chromium on the activity coefficient of oxygen in liquid iron 
This is not unreasonable in view of the fact that the chromium concentration did not exceed $10 \mathrm{wt} \%$ in the $\mathrm{CO} / \mathrm{CO}_{2}$ experiments and for this reason the uncertainty associated with the second order parameter is somewhat greater than that associated with the first.

Goto et al. ${ }^{38)}$ have measured the effect of chromium on the activity coefficient of oxygen in liquid iron at $1560^{\circ} \mathrm{C}$ using $\mathrm{CO} / \mathrm{CO}_{2}$ gas mixtures. Although they did not report a value for the interaction parameter $e_{0}^{\mathrm{Cr}}, \log f_{\mathrm{O}}^{\mathrm{Cr}}$ appeared to pass through a minimum point at about $7 \mathrm{wt} \%$ chromium. The reason for this behaviour, which is quite different from that observed during all other investigations, including the present work, is still unclear.

Various values for the first order free energy interaction parameter, $e_{0}^{\mathrm{Cr}}$, determined by different techniques are collected together in Table 2 and Fig. 7. Most of the determinations, including all of the EMF measurements, have been made in the vicinity of $1600^{\circ} \mathrm{C}$.

Three separate determinations have been made using lime-stabilized zirconia cells. ${ }^{12-14)}$ While all three values are in reasonable agreement, they correspond to the lowest values yet reported for the parameter. In contrast to the present work where $e_{0}^{\mathrm{Cr}}=$ -0.058 , the average value from the EMF measurements is -0.034 . A similar situation is found when the various data for vanadium-oxygen interactions are compared. ${ }^{12,15)}$ If cell characteristics are such that the measured EMF yields values which, although internally consistent, differ significantly from the true oxygen activity, then subsequent calculation will produce values which should be considered not as interaction parameters and activity coefficients in the accepted sense of the terms, but rather as " cell parameters" and "cell coefficients". These cell terms would be dependent not only on the alloy content of the steel, but also the composition and properties of the electrolyte. Thus when electrochemical cells are used to determine dissolved oxygen contents in practical steelmaking operations, misleading results could be obtained if cell readings are combined with interaction parameter data derived by techniques other than those involving the use of a similar cell. Further work is required in order to clarify the reasons for these discrepancies. From previous investigations in which data were collected over a temperature range, two expressions have been reported for the temperature

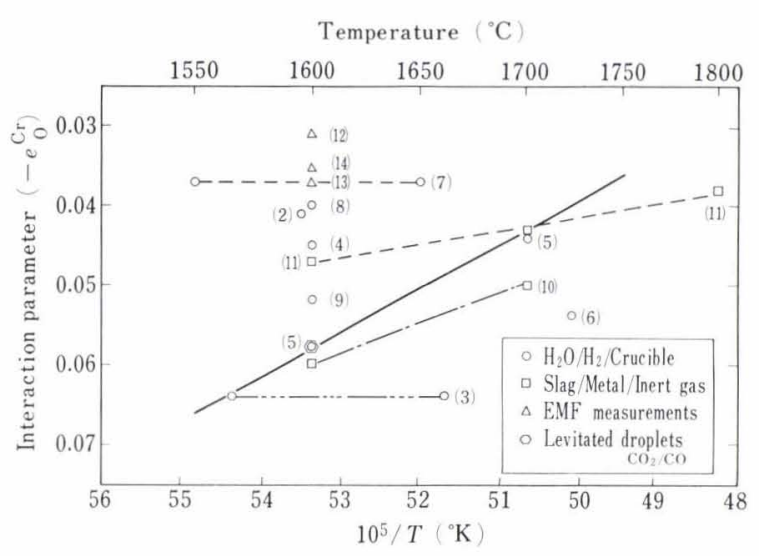

Fig. 7. Comparison of various data for the free energy interaction parameter, $e_{0}^{\mathrm{Cr}}$. The solid line corresponds to Eq. (11) from the present work and is based on $\mathrm{H}_{2} \mathrm{O} / \mathrm{H}_{2}$ experiments with levitated droplets. Reference numbers are in parentheses.

Table 2. Chromium-oxygen interactions in liquid iron

\begin{tabular}{|c|c|c|c|c|}
\hline & $\begin{array}{l}\text { Chromium range } \\
(w \mathrm{w} \%)\end{array}$ & $\begin{array}{l}\text { Temperature } \\
\left({ }^{\circ} \mathrm{C}\right)\end{array}$ & $\begin{array}{c}-e_{\mathrm{O}}^{\mathrm{Cr}} \\
\left(1600^{\circ} \mathrm{C}\right)\end{array}$ & Reference source \\
\hline $\begin{array}{l}\text { Water vapour/Hydrogen } \\
\text { experiments }\end{array}$ & $\begin{array}{l}0-10 \\
0-12 \\
0-30 \\
0-40 \\
0-10 \\
0-12 \\
0-7 \\
0-8\end{array}$ & $\begin{array}{c}1595 \\
1565-1660^{a)} \\
1600 \\
1600-1700 \\
1723 \\
1550-1650^{a)} \\
1600 \\
1600\end{array}$ & $\begin{array}{l}0.041 \\
0.064 \\
0.045^{b)} \\
0.058 \\
\left.0.058^{\mathrm{c}}\right) \\
0.037 \\
0.040 \\
0.052\end{array}$ & $\begin{array}{l}\text { Chen and Chipman }{ }^{1)} \text {; Chipman } \\
\text { Turkdogan } \\
\text { Sakao and Sano } \\
\text { Charlton and Ahmad } \\
\text { McLean and Bell } \\
\text { Matoba and Kuwana } \\
\text { Schenck and Steinmetz } \\
\text { Pargeter }^{8)}\end{array}$ \\
\hline $\begin{array}{l}\text { Slag/Metal/Inert gas } \\
\text { experiments }\end{array}$ & $\begin{array}{r}0-14 \\
10-25\end{array}$ & $\begin{array}{l}1600-1700 \\
1600-1800\end{array}$ & $\begin{array}{l}0.060 \\
0.047\end{array}$ & $\begin{array}{l}\text { Kojima and Sano }{ }^{10)} \\
\text { Nakamura, Ohno, and Segawa }{ }^{11)}\end{array}$ \\
\hline $\begin{array}{l}\text { Levitated droplets and } \\
\mathrm{H}_{2} \mathrm{O} / \mathrm{H}_{2}\end{array}$ & $0-24$ & $1550-1750$ & 0.058 & This study \\
\hline $\begin{array}{l}\text { Levitated droplets and } \\
\qquad \mathrm{CO}_{2} / \mathrm{CO}\end{array}$ & $0-10$ & 1600 & 0.058 & This study \\
\hline
\end{tabular}

a) The effect of temperature was not detectable.

b) For chromium concentrations below $10 \mathrm{wt} \%$.

c) Calculated assuming regular solution behaviour.

d) For chromium concentrations below 20wt \%. 
dependence of $e_{0}^{\mathrm{Cr}}$, viz:

Kojima and Sano, ${ }^{10)}$

$$
e_{\mathrm{o}}^{\mathrm{Cr}}=-369 / T+0.137
$$

and Nakamura et al., ${ }^{11}$

$$
e_{\mathrm{o}}^{\mathrm{Cr}}=-158 / \mathcal{T}+0.038 .
$$

In the study by Kojima and Sano, iron-chromium melts were equilibrated with silica saturated slags and calculation of the above equation required the assumption that the available data on the temperature dependence for the effect of silicon on the behaviour of oxygen in liquid iron were not only correct but also applicable to iron alloys containing chromium. Previous work on silicon-oxygen interactions ${ }^{6)}$ and a recent study on the effect of chromium on the behaviour of oxygen in liquid iron-chromium-vanadium alloys, suggest this may not be so. ${ }^{14)}$ Nevertheless, the agreement between the present investigation and the work of Kojima and Sano is good, particularly at $1600^{\circ} \mathrm{C}$. Since there is evidence ${ }^{14)}$ that parameters determined for ternary solutions may not be applicable to multi-component melts, the value reported by McLean and Bell for $e_{0}^{\mathrm{Cr}}$ at $1723^{\circ} \mathrm{C}$ may be too large. ${ }^{6)}$ This parameter was calculated from oxygen data for iron-chromium-aluminum melts and required the use of an aluminum-oxygen parameter evaluated from ternary solution data.

While the results from this study agree well with those of Nakamura et al. at $1700^{\circ} \mathrm{C}$, the variation of $e_{\mathrm{O}}^{\mathrm{Cr}}$ with temperature is greater. In their case, ${ }^{11)}$ no experiments were made with alloys containing less than $10 \mathrm{wt} \%$ chromium and only first order parameters were employed to express the effect of chromium on the activity coefficient of oxygen. In the absence of measurements in the dilute solution range, the magnitude of the interaction parameter was based on the behaviour of the more concentrated solutions assuming a linear extrapolation to infinite dilution. In view of the curvilinear relationships shown in Fig. 6, this would imply that chromium-oxygen interactions have been underestimated, particularly at $1600^{\circ} \mathrm{C}$, where the second order effect is most pronounced. As the temperature increases, the system becomes more Henrian in behaviour and the extent of this error would diminish. This would account for the smaller temperature dependence represented by Eq. (16).

Continuing the investigation begun by Charlton, ${ }^{5)}$ $\mathrm{Ahmad}^{5)}$ reported a value for $e_{0}^{\mathrm{Cr}}$ of -0.044 at $1700^{\circ} \mathrm{C}$. This is in very good agreement with the value derived from the droplet experiments and when taken together with Charlton's value of -0.058 at $1600^{\circ} \mathrm{C}$, corresponds to a temperature dependence for the interaction parameter which is almost identical to that represented by Eq. (11). Although a temperature dependence was not reported, the data of Turkdogan ${ }^{3)}$ are in good agreement with the present study at $1565^{\circ} \mathrm{C}$.

Recently Dondelinger et al. ${ }^{39)}$ have reported data for chromium-sulphur interactions in liquid iron which were determined by exposing levitated alloy droplets to $\mathrm{H}_{2} / \mathrm{H}_{2} \mathrm{~S}$ mixtures. These gases are even more susceptible to thermal diffusion than $\mathrm{H}_{2} / \mathrm{H}_{2} \mathrm{O}$, nevertheless, the parameters were in excellent agreement with those obtained by Ban-ya and Chipman ${ }^{40)}$ using a multiple crucible technique. The compatibility of the various data provides further confirmation that the levitation procedure can be employed to determine relative interactions in molten alloys, provided the gas composition at the droplet surface is not affected by the alloy content of the metal. This proviso also applies, of course, when gas/metal equilibria are investigated using crucible procedures. For example, it has been shown ${ }^{6}$ ) that published data ${ }^{41-43)}$ for silicon interactions in liquid iron exposed to $\mathrm{H}_{2} / \mathrm{H}_{2} \mathrm{O}$ mixtures, contain discrepancies which can be attributed to alterations in the oxygen potential of the gas phase due to the formation of silicon monoxide.

\section{Summary}

A study has been made of the dissolution of oxygen in liquid iron and iron-chromium alloys by equilibrating levitated droplets with $\mathrm{H}_{2} / \mathrm{H}_{2} \mathrm{O}$ and $\mathrm{CO} / \mathrm{CO}_{2}$ gas mixtures. Because of the presence of thermal diffusion, data from experiments of this type should not be employed to calculate equilibrium constants directly. Nevertheless, it has been proven that the levitation technique can be utilized to determine the relative effect of one alloying element on the chemical behaviour of another. During the present work it has been established that the effect of chromium on the activity coefficient of oxygen in liquid iron is given by:

$$
\begin{aligned}
\log f_{\mathrm{o}}= & (-557.8 / T+0.240)[\% \mathrm{Cr}] \\
& +\left(12.97 / T-6.29 \times 10^{-3}\right)[\% \mathrm{Cr}]^{2}
\end{aligned}
$$

This equation is based on data derived from equilibration of $\mathrm{H}_{2} / \mathrm{H}_{2} \mathrm{O}$ gas mixtures with iron alloys containing up to $24 \mathrm{wt} \%$ chromium at temperatures between $1550^{\circ}$ and $1750^{\circ} \mathrm{C}$. Data from $\mathrm{CO} / \mathrm{CO}_{2}$ experiments at $1600^{\circ} \mathrm{C}$ with iron droplets containing up to $10 \mathrm{wt} \%$ chromium are in good agreement with this expression.

While the value for $e_{0}^{\mathrm{Cr}}$ of -0.058 at $1600^{\circ} \mathrm{C}$ is consistent with several previous studies based both on gas/metal and slag/metal, crucible experiments, it indicates a much stronger chromium-oxygen interaction than that suggested by recent electrochemical measurements with lime-stabilized zirconia cells. Further work is required in order to clarify the reasons for this discrepancy.

Advantages of the levitation procedure include: elimination of melt contamination by refractories, rapid attainment of equilibrium, and avoidance of analytical errors caused by solute segregation within samples.

\section{Acknowledgements}

Acknowledgements are due to the National Research Council of Canada who have provided financial support for this project as part of a programme on solute interactions in steel. One of the authors (F. C. L. L.) is grateful to the Canada Council for a scholarship award. 


\section{REFERENCES}

1) H. M. Chen and J. Chipman: Trans. ASM, 38 (1947), 70.

2) J. Chipman: JISI, 180 (1955), 97.

3) E. T. Turkdogan: JISI, 178 (1954), 278.

4) H. Sakao and K. Sano: J. Japan Inst. Met., 26 (1962), 236.

5) K. Charlton: Ph. D. Thesis, Univ. Glasgow, (1963).

A. Ahmad: Ph. D. Thesis, Univ. Glasgow, (1967).

6) A. McLean and H. B. Bell: JISI., 203 (1965), 123.

7) S. Matoba and T. Kuwana: Tetsu-to-Hagané Overseas, 5 (1965), 187.

8) H. Schenck and E. Steinmetz: Arch. Eisenhüttenw., 38 (1967), 871.

9) J. K. Pargeter: Can. Met. Quart., 6 (1967), 21.

10) Y. Kojima and K. Sano: Tetsu-to-Hagané Overseas, 5 (1965), 11.

11) Y. Nakamura, T. Ohno, and K. Segawa: Proc. ICSTIS, (1971), 456, Suppl. Trans. ISIJ.

12) W. A. Fischer and M. Haussmann: Arch. Eisenhüttenw., 37 (1966), 959 .

13) R.J. Fruehan: Trans. TMS-AIME, 245 (1969), 1215.

14) P. A. Cerkasov and W. A. Fischer: Arch. Eisenhüttenw., 42 (1971), 699

15) P. Kershaw, A. McLean, and R. G. Ward: Can. Met. Quart., 11 (1972), 327.

16) G. P. Baxter and J. E. Lansing: J. Amer. Chem. Soc., 42 (1920), 419.

17) J. B. Bookey: JISI, 172 (1952), 66; 86.

18) H. F. Ramstad and F. D. Richardson: Trans. TMS-AIME, 221 (1961), 1021.

19) A. M. Smellie and H. B. Bell: Can. Met. Quart., 11 (1972), 351.

20) M.N. Dastur and J. Chipman: Trans. TMS-AIME, 185 (1949), 441

21) T. P. Floridis and J. Chipman: Trans. TMS-AIME, 212 (1958), 549.

22) G. W. Toop and F. D. Richardson: Advances in Extractive Metallurgy, Inst. of Mining and Met., London, (1967), 181.

23) E. S. Tankins, N. A. Gokcen, and G. R. Belton: Trans.
TMS-AIME, 230 (1964), 820.

24) H. C. Vacher: Journal of Research, 11 (1933), 541, U.S. Bureau of Standards.

25) G. Phragmen and B. Kalling: Jernkontorets Annaler., 123 (1939), 199.

26) S. Marshall and J. Chipman: Trans. ASM, 30 (1942), 695.

27) N. A. Gokcen: Trans. TMS-AIME, 206 (1956), 1558.

28) S. Matoba and S. Ban-ya: Japan Soc. for the Promotion of Science, 19th Committee, (1959), Tech. Paper 5436.

29) J. F. Elliott, M. Gleiser, and V. Ramakrishna: Thermochemistry for Steelmaking, II (1963), Addison-Wesley Press, Mass.

30) V. V. Averin, A. Y. Polyakov, and A. M. Samarin: Izv. Akad. Nauk. SSSR, Otd. Tekhn. Nauk, 3 (1955), 90.

31) H. Sakao and K. Sano: Trans. JIM, 1 (1960), 38.

32) M. Sunderland, A. E. Hamielec, W-K. Lu, and A. McLean: Met. Trans., 4 (1973), FEB.

33) C. Wagner: Thermodynamics of Alloys, (1952), 51, Addison-Wesley Press, Mass.

34) C. H. P. Lupis and J. F. Elliott: Trans. TMS-AIME, 233 (1965), 257.

35) C. H. P. Lupis and J. F. Elliott: Trans. TMS-AIME, 233 (1965), 829

36) C. H. P. Lupis and J. F. Elliott: Acta Met., 14 (1966), 529.

37) C. H. P. Lupis and J. F. Elliott: Acta Met., 15 (1967), 265.

38) K. Goto, S. Ban-ya, and S. Matoba: Tetsu-to-Hagané Overseas, 3 (1963), 184.

39) J. G. Dondelinger, D. A. R. Kay, and A. McLean: Met. Trans., 2 (1971), 3203.

40) S. Ban-ya and J. Chipman: Trans. TMS-AIME, 245 (1969), 133

41) N.A. Gokcen and J. Chipman: Trans. TMS-AIME, 194 (1952), 171; 197 (1953), 1017.

42) S. Matoba, K. Gunji, and T. Kuwana: Tetsu-to-Hagané, 45 (1959), 1328.

43) J. Chipman and T. C. M. Pillay: Trans. TMS-AIME, 221 (1961), 1277. 